\title{
Šetnja od Trga žrtava fašizma do Parka ponosa: semiotička analiza simboličkog preimenovanja ulica na zagrebačkoj Povorci ponosa kao prakse pamćenja
}

\author{
MISLAVA BERTOŠA \\ Odsjek za lingvistiku, \\ Filozofski fakultet Sveučilišta u Zagrebu \\ SANDRA ANTULOV \\ Rijeka
}

\begin{abstract}
U radu se analizira čin simboličkog preimenovanja ulica uključenih u rutu zagrebačke Povorke ponosa koji se, zasad jednokratno, dogodio 2010. godine. Promatran je kao praksa s pomoću koje se konstituira i komunicira kolektivno pamćenje jedne marginalizirane skupine. Perspektiva u ovome radu je semiotička: čin preimenovanja ulica promatra se u okviru odnosa između konstrukcija značenja, povijesti i pamćenja. Na primjerima preimenovanih ulica, trgova i parkova pokazuje se koji sve značenjski elementi sudjeluju u toj konstrukciji. Promatrana je, s jedne strane, evokacija različitih značajnih trenutaka globalne LGBT povijesti, a s druge strane lokalni (zagrebački, nacionalni, srednjoeuropski) elementi. Također se istražuju načini na koje se lokalni i globalni elementi međusobno isprepliću i rekontekstualiziraju u današnjem kontekstu te odnos koji uspostavljaju s poviješću i prostorom (centar glavnoga grada Republike Hrvatske) u koje se upisuju.
\end{abstract}

Ključne riječi: hodonimi, preimenovanje, jezični/semiotički krajolici, semiotika, pamćenje, toponimski otpori

\section{PAMĆENJE U SEMIOTIČKOJ PERSPEKTIVI}

U semiotičkoj perspektivi, posebice onoj strukturalističke provenijencije, koja vuče svoje korijene od Saussurea preko Hjelmsleva do Greimasa i njegovih nastavljača, procesi pamćenja nerijetko se opisuju semičkim kategorijama koje se sastoje od opozicija dvaju različitih značenja koja međusobno nisu povezana unaprijed određenim logičkim odnosom, nego suprotno, opozici- 
jom smisla povezanom s konkretnim funkcioniranjem u određenom tekstu. ${ }^{1}$ Jedna od temeljnih opozicija, primjenjiva i na temu koja se obrađuje u ovome radu, jest ona između čuvanja i zaborava (Demaria 2006: 100). Čuvanje u najširem smislu, i materijalnom i simboličkom, koje uključuje različite oblike ljudskog konzerviranja pamćenja od arhiva i muzeja preko memorijalnih praksi, rituala i obilježavanja traumatičnih događaja do proizvoda i likova popularne i masovne kulture, postoji i razvija se samo u opreci prema zaboravu koji se u ovoj perspektivi promatra kao integrirani dio pamćenja, jer je pretpostavka da se čovjek može sjećati samo ako je u stanju i zaboraviti. No, kad je riječ o kulturnim ili društvenim kontekstima unutar kojih ova semička kategorija dobiva svoje funkcije, zaborav se ne određuje kao individualna nesvjesna aktivnost koja se "normalno" događa zato što većina ljudi jednostavno nije u stanju sve pamtiti, već se njemu prilazi kao namjernoj strategiji i resursu, kao direktivu, ili, riječima Aleide Assmann (2011), kao "naloženom" zaboravu.

Bez obzira na to što kao namjerna strategija ima specifične funkcije i ciljeve, zaborav kao sastavni dio semičke kategorije također postoji i razvija se samo u opoziciji s čuvanjem. Dinamičnost i uzajamna uvjetovanost njihova odnosa u semiotičkom viđenju u određenom povijesno-društvenom kontekstu može dovesti do obrtanja značenja i vrijednosti upisanih u tu kategoriju, pa ono što je u nekim razdobljima bilo čuvano može u jednome trenutku biti prepušteno zaboravu, dok ono što je bilo zaboravljeno može zaživjeti na drugoj strani procesa pamćenja - u čuvanju.

U takav interpretacijski okvir uklapa se tema ovoga rada - prakse pamćenja jedne marginalizirane skupine, LGBT populacije, koja je ne samo u Hrvatskoj već i na globalnoj razini ključne trenutke svoje povijesti i kulture $\mathrm{u}$ jednome trenutku počela izvlačiti iz zaborava koji je trajao stoljećima. Budući da je LGBT populacija kao marginalizirana skupina bila "izbačena" iz službenih verzija povijesti i budući da su njezine uloge bile prešućene, a postojanje ignorirano, važnost stvaranja vlastite povijesti, identiteta i "mjesta pamćenja" (Nora 2006), dobiva posebnu težinu. Poput svake društvene skupine, i marginalizirana skupina razrađuje specifične modalitete komemoracije na temelju vlastitih vrijednosti i na temelju vlastite vizije svijeta. Izostanak iz "službene" povijesti određuje potrebu za stvaranjem "vlastite" povijesti, a to se ostvaruje upravo rekonstrukcijom pamćenja. Utoliko se o kolektivnom pamćenju može govoriti kao o onome što ostaje od prošlosti u viđenju određenih skupina, ili o onome što te skupine čine od prošlosti (Nora 2006; Le Goff 1977: 394). Osim stvaranja vlastite povijesti i mjesta

\footnotetext{
${ }^{1}$ Rad predstavlja razrađenu i izmijenjenu verziju pozvanog izlaganja pod naslovom “Živjela perverzija na Lezbožednom trgu: slogani i simboličko preimenovanje ulica na zagrebačkoj povorci ponosa kao prakse pamćenja" koje su autorice održale 22. svibnja 2012. godine u okviru projekta Kulturne memorije voditeljice prof. dr. sc. Senke Božić Vrbančić u zagrebačkom Centru za kulturu Trešnjevka.
} 
pamćenja, postavlja se i pitanje stvaranja identiteta, a oni se također kreiraju polazeći od iščitavanja i neprestanih reinterpretacija vlastite prošlosti. Le Goff pamćenje proglašava esencijalnim elementom identiteta (Le Goff 1977: 397), dok Violi ističe da je pamćenje esencijalno za stvaranje kolektivnih i individualnih identiteta, te naglašava da je proces konstrukcije identiteta na društvenoj razini reguliran upravo politikama pamćenja (Violi 2009). Kako će biti pokazano, uz neprestana iščitavanja prošlosti i sadašnjosti, postoji i usmjerenost prema budućnosti koja svoju posebnu funkciju ostvaruje $u$ aktivističkim borbama za poboljšanje prava, viši stupanj tolerancije i veću vidljivost kako na simboličkoj tako i na stvarnoj, materijalnoj razini.

No razrade specifičnih modaliteta komemoracija, reinterpretacije prošlosti i pokušaji upisivanja u službene verzije povijesti te konstrukcije vlastitih identiteta nikada neće u cijelosti biti ozbiljeni ako s pomoću komunikacijskih i općenito ljudskih znakovnih praksi ne uđu u prostore javnih diskursa i u njima budu prihvaćeni. U tom segmentu jeziku i ostalim sustavima znakova pripada najvažnija uloga. Kako je još u sedamdesetim godinama prošlog stoljeća napominjao Atlan (prema Le Goff 1977: 348-349) jezik, najprije govoren, a zatim i pisan, predstavlja izvanredan produžetak mogućnosti uskladištenja ljudskog pamćenja kojemu je na taj način omogućeno da izađe iz ograničavajućih prostora ljudskog tijela i uđe u tuđa pamćenja u međugeneracijskoj perspektivi, u arhive, biblioteke, muzeje itd. Odnosno, kako je puno prije njega napominjao Halbwachs, sjećanja, pa i ona najintimnija, proizlaze iz komunikacije i interakcije društvenih grupa (Halbwachs 1992; vidi i Assmann 2006: 53). Iz njegova se polazišta može zaključiti da je ključna uloga komunikacije, dakle, jezika i ljudske znakovne prakse općenito, kao i interpersonalne i međugrupne interakcije, bila gotovo od početka prepoznata kao nezaobilazan dio konstrukcije i rekonstrukcije pamćenja. Iz komunikacije, prema Halbwachsu, proizlazi i temeljna funkcija sjećanja, a to je da individuu poveže s različitim društvenim skupinama poput, primjerice, vlastite obitelji, prijatelja, ali i vjerskih i nacionalnih skupina i zajednica. Pamćenje tako živi i traje u komunikaciji, a ako komunikacija prestane, pojavljuje se zaborav. $\mathrm{Na}$ taj način, individue pamte samo one stvari i događaje, samo ona iskustva koja mogu smjestiti u kolektivno pamćenje. Drugim riječima, o onome što će se pamtiti, a što će se zaboraviti ne odlučuju sami pojedinci nego "socijalni okviri" pamćenja: društvene veze, identiteti, grupne solidarnosti (Halbwachs 1992).

$\mathrm{Na}$ tim se tezama može dograđivati semiotički pristup procesima pamćenja. Taj pristup ima različita polazišta, metodološke i teorijske okvire, a svojem najtemeljnijem obliku pamćenju prilazi preko tekstova ili diskursa koji se mogu analizirati metodama klasične semiologije. U takvu teorijskom okviru važnu ulogu dobiva Greimasov pojam narativnosti jer predstavlja onaj dispozitiv preko kojega se selekcija materijala za pamćenje 
i konstrukcija njegove relevantnosti uopće događa. Narativna i diskurzivna selekcija i reorganizacija određenih elemenata iz prošlosti nauštrb drugih imaju ključnu ulogu i u konstrukciji identiteta. Moglo bi se, nadalje, tvrditi da su se semiotika kulture i sociosemiotika, baveći se procesima semioze u određenim kulturama i načinima na koje se društveno samopredstavlja i stvara, odražava i modificira u tekstovima i diskursima koje samo proizvodi, oduvijek, pa makar i posredno, bavile procesima pamćenja. ${ }^{2}$

U semiotičkoj perspektivi pamćenju se ne prilazi kao "prirodnoj" danosti, već kao skupu reprezentacija koje su plod procesa neprekidnog pregovaranja između različitih aktera i njihovih identiteta (Demaria 2006: 43). Utoliko se pamćenje može odrediti kao društvena praksa. Pri svim opisanim dimenzijama procesa pamćenja stvara se ono što Violi naziva sustavom memorije: semiotika nastoji osvijetliti i proučiti "lokalne enciklopedijske mreže koje oblikuju kolektivnu memoriju zajedno s njezinim modifikacijama i dijakronijskim transformacijama" (Violi 2010: 14).

\section{IMENOVANJE I PREIMENOVANJE ULICA U KONTEKSTU ISTRAŽIVANJA SEMIOTIČKIH KRAJOLIKA I SEMIOTIKE PROSTORA}

Imena ulica ili kraće hodonimi (Skračić 2011: 119) u istraživanjima jezičnih i semiotičkih krajolika promatraju se kao javni znakovi. Spolsky (2009: 28; vidi i Landry i Bourhis 1997) navodi dvije temeljne funkcije koje javni znakovi mogu obavljati u javnom prostoru: prva je komunikacija (koja može uključivati prenošenje obavijesti, ${ }^{3}$ upućivanje ${ }^{4}$ ili poduzimanje uvjeravačkih aktivnosti ${ }^{5}$ ), a druga izražavanje simboličke funkcije kojoj pripisuje dvije dodatne podfunkcije - označivanje jezične dominacije ${ }^{6}$ ili proglašavanje vlasništva nad čim. ${ }^{7}$ Hodonimi su primarno javni znakovi sa simboličkom funkcijom,

\footnotetext{
${ }^{2}$ Semiotički analitički modeli imaju razvijene prikladne instrumentarije za analize narativnih identiteta, za interpretacije procesa konstrukcije neke nacije, za istraživanje ljudskih običaja i znakovnih praksi, za analize simboličkih i prostornih organizacija najraznolikijih mjesta pamćenja itd. I to i u verbalnim i u neverbalnim (vizualnim, taktilnim, auditivnim...), odnosno multimodalnim semiotičkim načinima konstrukcije i reprezentacije procesa pamćenja i njihovih produkata.

${ }^{3}$ Primjerice, ploče s tekstovima koje su postavljene u blizini nekog spomenika, građevine, arheološkog nalazišta itd. Ponajprije su namijenjene turistima, a tekstovi sadržavaju osnovne informacije o objektu (povijesnom kontekstu nastanka, okolnostima gradnje, karakteristikama...) na koji se odnose.

${ }^{4}$ Primjerice, prometni znakovi koji referiraju na zabranu parkiranja, kretanja u propisanom smjeru vožnje i sl.

${ }^{5}$ Primjerice, reklame na plakatima i panoima, u izlozima trgovina i sl.

${ }^{6}$ Tipično se ostvaruje u dvojezičnim područjima i u podijeljenim gradovima u kojima postoji borba za prevlast između govornika dvaju (ili više) jezika.

${ }^{7}$ Primjerice, ploče na zgradama koje su u vlasništvu državnih ili vladinih institucija; ili markiranje privatnih posjeda.
} 
dok u sekundarnim funkcijama mogu markirati jezičnu dominaciju (kad je riječ o dvojezičnim ili višejezičnim natpisima, odnosno dvojezičnim pločama s imenima ulica) ili prenositi i dodatnu obavijest (ukoliko su na pločama osigurane dodatne informacije o hodonimu; primjerice, tko je bila osoba po kojoj je ulica dobila ime, kad je živjela i sl.).

U suvremenim se semiotičkim istraživanjima, koja se nadograđuju na istraživanja semiotičkih krajolika i upotpunjuju ih svojim pristupima i perspektivama, hodonimi mogu promatrati kao oblik prostorne inskripcije. $S$ pomoću njih javni se prostor najčešće obilježava imenima osoba ${ }^{8}$ ili simbolima koji se smatraju relevantnima za javnost, povijest i kolektivne identitete. ${ }^{9}$ Utoliko hodonimi funkcioniraju i kao mjesta pamćenja (Isnenghi 1997: XII). Imenovanje ulica i trgova, stoga, ima "konstitutivnu ulogu u društvenoj proizvodnji 'mjesta'" (Rose-Redwood i sur. 2010: 456), a uz primarnu, praktičnu funkciju omogućavanja lakše orijentacije u prostoru te administrativne regulacije i kontrole urbanog prostora, ono ima i simboličku funkciju proizvodnje zajedničke prošlosti (Azaryahu 1996). Kako je imenovanje (i preimenovanje) ulica i trgova, kao i postavljanje ploča s njihovim nazivima, zakonski regulirano i u ovlasti državne ili lokalne uprave, ta "naizgled administrativna procedura postaje izraz moći" (Azaryahu 1996: 313). Ono, dakle, služi i kao način društveno-političke kontrole prostorâ u kojima živimo (Scollon i Wong Scollon 2003). Usprkos tome što je imenovanje ulica i trgova privilegija dominantnih skupina, podređene grupe mogu - a to i rade - izvoditi činove preimenovanja mjesta, preoblikovanja toponimskoga krajolika, kao načina toponimskog otpora (Rose-Redwood i sur. 2010), odnosno simboličkog otpora ideologiji dominantnih skupina.

Godine 2010. organizatori zagrebačke Povorke ponosa izmislili su "nova" imena za ulice i trgove na ruti kojom se povorka kretala. Na ulasku u ulicu ili dolasku na trg organizatori bi megafonom najavili promijenjeno ime i nosili ga kao transparent do sljedeće ulice ili trga. Nova imena nisu referirala na konkretne i stvarne osobe, već su odavala počast anonimnim članovima LGBT zajednice i sadržavala simbole važne za tu populaciju. Tim je trans-

\footnotetext{
${ }^{8}$ Skračić napominje da hodonimi "obično dolaze od antroponima, jer se ulice posvećuju uglednim pojedincima” (2011: 119), no ističe visok stupanj podložnosti preimenovanjima za koje izdvaja dva temeljna razloga: prvi se odnosi na stanovnike koji se veoma često ne obaziru na trenutačne sustave imena ulica, već ulice (i četvrti) nazivaju onako kako su ih nazivali i njihovi preci, odnosno kako je to uobičajeno u tradiciji; Rihtman-Auguštin (2000) to naziva pučkim odmakom od političke prinude. Drugi se razlog tiče činjenice da se imena ulica najčešće određuju postupkom koji je unaprijed određen i uređen - Skračić ga naziva oktroiranim imenovanjem i suprotstavlja spontanom načinu pripisivanja imena ulicama, trgovima i gradskim četvrtima koje poduzimaju sami stanovnici. Riječ je o dvama temeljnim načinima imenovanja ulica, trgova i četvrti koji odgovaraju Ben-Rafaelovim (2009) pojmovnim parovima top - down (oktroirano) i bottom - up (spontano) te Calvetovim znakovima in vitro i znakovima in vivo (cit. prema Backhaus 2006).

${ }^{9}$ Iako se može obilježavati i brojevima, što je čest slučaj u SAD-u (primjerice, čuvena Peta Avenija u New Yorku).
} 
gresivnim činom (Scollon i Wong Scollon 2003) Povorka ponosa djelovala dvojako: (1) iskazala je svoje nezadovoljstvo heteronormativnošću centra grada te je u njega intervenirala, pokvirila ${ }^{10}$ ga, podredila svojim potrebama i kreirala jedno sasvim drukčije mjesto, jedan sasvim drukčiji krajolik - koji se može odrediti kao queer krajolik i (2) istodobno je konstrukcijom zajedničke povijesti i revidiranjem opće povijesti pridonijela formiranju i jačanju zajedničkog identiteta. Utoliko je transgresivnost preimenovanja ulica koje su simbolički napravili LGBT aktivisti u Povorci ponosa 2010. godine bila dvostruka: (1) sam čin preimenovanja nije ovlašten (izvršila ga je podređena i marginalizirana grupa) i (2) "nova" imena protivna su očekivanjima, nisu "prikladna".

\section{SEMIOTIČKI POGLED NA ZAGREBAČKU POVORKU PONOSA}

Zagrebačka Povorka ponosa održava se od 2002. godine. Započela je kao aktivistički pokret kojim se željelo upozoriti javnost na sustavnu diskriminaciju i kršenje ljudskih prava seksualnih i rodnih manjina u Hrvatskoj. U prvoj je Povorci sudjelovalo oko dvjesto ljudi koji su bili izloženi velikom verbalnom nasilju, a na sudionike je bio bačen i suzavac. U recentnije vrijeme u zagrebačkoj Povorci sudjeluje više od dvije tisuće ljudi, dok i sama Povorka dobiva sve masovniju podršku medija i osoba iz javnoga kulturnog i političkog života. Bez obzira na puno pozitivnih promjena i pomaka koji su se od održavanja prve Povorke ponosa odvili u hrvatskome društvu, njezino je temeljno i dominantno obilježje i dalje aktivistička borba za vidljivost i priznanje prava LGBT populacije, te se utoliko zagrebačka Povorka razlikuje od Povorki koje se odvijaju u velikim svjetskim i europskim urbanim centrima, poput, primjerice, Sidneyja, Berlina ili Rima, kojima se u literaturi nerijetko pripisuje poticanje konzumerističkih vrijednosti, hedonizma, ludizma, slavlja i zabave, privlačenje turista iz cijeloga svijeta te elitizam (Johnston 2002; Luongo 2002). Te karakteristike pokazuju da su spomenute Povorke ponosa dobro uklopljene u današnje društvo spektakla, a to ih u određenoj mjeri distancira od prvotne ideje aktivizma i borbe za priznavanje prava.

Svojim činom kretanja kroz javni prostor Povorka ponosa prisvaja ${ }^{11}$ javni gradski prostor i upotrebljava ga kao sredstvo za stvarnu i simboličku konstrukciju i reprezentaciju vlastitih povijesti, identiteta i pamćenja. Smještaju-

${ }^{10} \mathrm{O}$ zagrebačkoj Povorci ponosa kao dekonstrukcijskoj spacijalnoj taktici i taktikama pokvirivanja gradskoga središta s pomoću slogana nošenih na povorci više u Bertoša i Antulov (2012: 775 i dalje). 0 pojmu pokvirivanja i objašnjenju upotrebe upravo takve grafijske varijante vidjeti posebno bilješku 7 na str. 789.

${ }^{11}$ U lingvistici se pojam prisvajanja (eng. appropriation) definira kao čin kojim se sredstva koja se doživljavaju i percipiraju kao tuđa preuzimaju i upotrebljavaju za promicanje vlastitih ciljeva (Shugart 1997: 
ći u gradsko središte ${ }^{12}$ vlastite diskurse koji nose sustave vrijednosti koji nisu općeprihvaćeni i u cijelosti tolerirani u današnjem hrvatskom društvu, ta masa ljudskih tijela formiranih u povorku iskazuje i veliča vlastite ideologije i životne stilove. U tome kontekstu može se govoriti o pokvirivanju gradskoga središta za vrijeme održavanja Povorke ponosa i popratnih programa. ${ }^{13}$

Povorka ponosa, međutim, u drukčijoj semiotičkoj perspektivi može biti promatrana i kao mjesto pamćenja, odnosno kao praksa s pomoću koje se ono stvara i perpetuira. Nastanak pojma "mjesta pamćenja" Nora (2006: 28) povezuje sa zajednicama koje ih, ponesene promjenama, stvaraju, uspostavljaju, proglašavaju te umjetno i namjerno održavaju. U svjetonazorskom sustavu Povorke ponosa dominantan je specifičan spoj globalnosti, internacionalnosti i regionalnosti, obilježja koja se podjednako, kako će biti pokazano, mogu iščitati iz sustava novoimenovanih ulica i trgova. Kao bitan element $u$ konstrukciji zajedničke povijesti i kolektivnog identiteta LGBT populacije u Hrvatskoj, prisvajaju se internacionalni konteksti održavanja Povorki ponosa te posebice američka povijesna pozadina za koju mnogi povjesničari tvrde da je odigrala pionirsku ulogu u "rasplamsavanju gej revolucije" (Carter 2011). Na stranicama udruge koja svake godine organizira zagrebačku Povorku ponosa može se pročitati: "Povorka ponosa Zagreb Pride sebe smatra sljednicom međunarodnog Pride pokreta, nastalog na Stonvolškoj pobuni i 'Gay Liberation Frontu'". ${ }^{14}$ Bitne su, međutim, i lokalne, regionalne (balkanske) mreže povezivanja i solidarnosti: "Zagreb Pride ima snažan regionalni karakter i podržava sudjelovanje LGBTIQ osoba iz zapadno balkanske regije na zagrebačkoj Povorci ponosa." ${ }^{15}$

210). Sredstva koja se prisvajaju mogu biti raznoliki kulturni proizvodi i prakse, primjerice odijevanje, glazba, znanstveno znanje, jezik, žanrovi, stilovi, simboli, prostori itd.

${ }^{12}$ Definicija središta grada preuzeta je od Ben-Rafaela, koji ga određuje kao dio grada u kojem "možemo vidjeti gužvu kad je većina ljudi na poslu" (2009: 41).

${ }^{13}$ Time Povorka ponosa pretvara prostor javnoga gradskog središta u simbolički i metaforički prostor koji "aktualizira" alternativni model stvarnosti, dakle, u prostor koji bi odgovarao McHaleovu (1992: 250) konceptu zone.

${ }^{14}$ Dostupno na: http://www.zagreb-pride.net/web/index.php?option=com_content\&view=article\&i $\mathrm{d}=145 \&$ Itemid=105\&lang=hr (pristup svibanj 2015.).

${ }^{15}$ Dostupno na: http://www.zagreb-pride.net/web/index.php?option=com_content\&view=article\&i $\mathrm{d}=145 \&$ Itemid=105\&lang=hr (pristup svibanj 2015.). Regionalni karakter i orijentacija prema osobama iz zapadnog balkanskog područja u vezi je s (neuspješnim) počecima organizacije Povorke ponosa u susjednoj Srbiji. Na stranicama Zagreb Pridea piše: “Prva zagrebačka Povorka ponosa organizirana je 29. lipnja 2002. godine na poticaj lezbijske aktivističke zajednice zbog traumatičnog iskustva nekoliko žena iz Hrvatske nakon pokušaja obilježavanja Dana ponosa LGBT osoba u Beogradu godinu dana ranije." (dostupno na: http://www.zagreb-pride.net/web/index.php?option=com_content\&view=article\&id=145\&Itemid=105\&lang=hr; pristup listopad 2015. godine).Još jedan bitan element Povorke ponosa u kojem su također prisutne evokacije globalnih i lokalnih mjesta kolektivne memorije LGBT populacije su slogani. Nezaobilazni su u različitim prosvjedima, demonstracijama i pobunama, a u takvim okolnostima dolazi do izražaja njihova sposobnost evociranja određenih stavova, ideologija, sustava vrijednosti za koje se prosvjednici, aktivisti ili borci za nečija prava zalažu. Uz to, prisutne su i konstrukcije i reprezentacije 
Kao aktivistička praksa koja se odvija tijekom subotnje špice u središtu glavnoga grada Republike Hrvatske, Povorka ponosa evocira dva ključna pojma: prvi je pojam iskoraka (eng. coming out), koji se gradi u značenjskoj opreci prema skrivanju, dok je drugi pojam ponosa, koji je povezan sa samim iskorakom i koji se razvija u značenjskoj suprotnosti sa sramom zbog vlastite orijentacije. Ti pojmovi čine dvije semičke kategorije: skrivanje - iskorak i sram - ponos, koji se mogu kombinirati i prikazati s pomoću semiotičkoga četverokuta (Greimas i Rastier 1968; Floch 1997a; Floch 1997b; vidi shemu 1).

$\begin{array}{ll}\begin{array}{l}\text { SVAKODNEVICA } \\ \text { prošlost, (nerijetko) i sadašnjost } \\ \text { (stvari kakve jesu) }\end{array} & \begin{array}{l}\text { AKTIVIZAM } \\ \text { budućnost } \\ \text { (stvari kakve bi trebale biti) }\end{array}\end{array}$

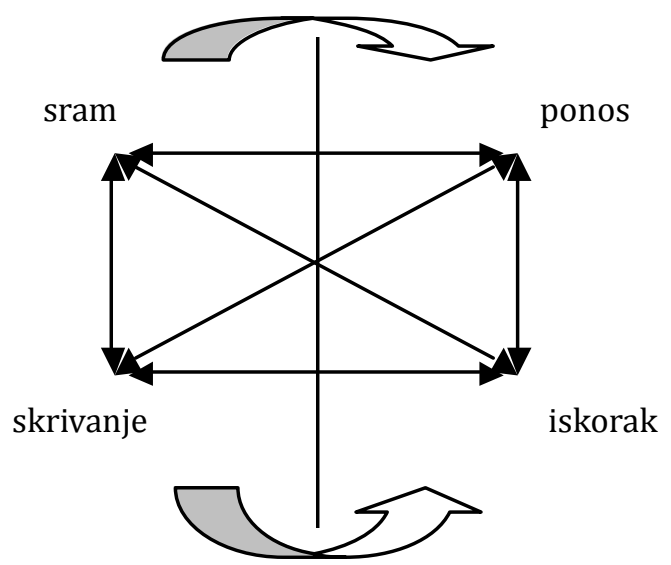

Shema 1: Prikaz dubinske značenjske organizacije Povorke ponosa s pomoću semiotičkog četverokuta

Na jednoj strani postoje sram i skrivanje koji obilježavaju svakodnevicu mnogih LGBT osoba kako u Hrvatskoj tako i drugdje: tako je bilo u prošlosti, ali nerijetko je i u sadašnjosti isto tako - to je onako kako jest, to je svakodnevica velikoga broja LGBT osoba. Na drugoj strani postoje ponos i iskorak koji označuju aktivno djelovanje usmjereno prema budućnosti - prema onome kako bi trebalo biti. Aktivizam je tu smješten na stranu na kojoj se nalazi budućnost, jer njegovo djelovanje upravo sada određuje kakve će stvari biti u vremenu koje tek treba doći. Te se dvije strane, dakako, nalaze u stalnoj

kolektivnih identiteta, što se nerijetko postiže upravo evokacijom općih mjesta pamćenja određenih skupina (o ulozi slogana u dekonstrukciji javnoga heteronormativnog prostora vidi Bertoša i Antulov 2012). 
relaciji i ne mogu postojati jedna bez druge. ${ }^{16}$ Pojmovi ponosa i iskoraka impliciraju jedan drugi i nalaze se u neprekidnoj relaciji prema sramu i skrivanju, koji se također međusobno impliciraju. Posljednja relacija koja je prikazana s pomoću semiotičkog četverokuta uključuje kombinacije dviju semičkih kategorija koje su u četverokutu povezane dvjema dijagonalama: to su kategorije srama i iskoraka te ponosa i skrivanja. ${ }^{17}$ Te dvije semičke kategorije, članovi kojih se nalaze u relaciji kontradiktornosti, vjerojatno najbolje odražavaju životnu realnost mnogih LGBT osoba i patemičku dimenziju njihova postojanja kao semiotičkih subjekata. Prva semička kategorija opisuje subjekte stiješnjene između osjećaja srama zbog svoje različitosti i nemogućnosti da se uklope u imperative heteronormativnoga društva te konstantne intimne potrebe da javno obznane svoju spolnu orijentaciju i kao takvi budu prihvaćeni u društvenim grupama dijelom kojih se osjećaju. Druga semička kategorija opisuje subjekte koji su pritisnuti između osjećaja ponosa zbog pripadnosti LGBT zajednici te straha koji ih prisiljava da ne obznane svoju spolnu orijentaciju, da ne iskorače, već da nastave sa životom "u ormaru", onemogućeni da u cijelosti "žive svoju integraciju u različitim društvenim skupinama" (Greimas 1991: 44). U oba slučaja proturječna smjesa disforičnih (sram, skrivanje) i euforičnih (ponos, iskorak) strasti u kojoj su mnoge LGBT osobe prisiljene svakodnevno egzistirati snažno utječe na obilježja i dinamiku njihovih "sociosemiotičkih uloga" u kojima sudjeluju kao semiotički subjekti (Greimas 1991: 48, 54). U tim relacijama dolazi do izražaja važnost pragmatičke, pasionalne (patemičke) i somatske dimenzije ljudske afektivnosti jer su upravo one te koje potiču na konkretna djelovanja, uspostavljaju intersubjektivne i međugrupne odnose, aktiviraju strasti i afektivna stanja subjekata ili različitih skupina. ${ }^{18}$

Ključni pojmovi i temelj na kojima svaka Povorka deklarativno počiva nisu, međutim, sram i skrivanje, nego iskorak i ponos. Kao aktivistička insti-

${ }^{16}$ U klasičnoj verziji iz 1968. godine odnosi unutar semiotičkog kvadrata, osim temeljne semičke kategorije, bili su prikazani kao dvosmjerni (vidi Greimas i Rastier 1968). U kasnijim brojnim primjenama na najrazličitija područja ljudskog iskustva i djelovanja odnosi kontradikcije i implikacije nerijetko su se prikazivali kao jednosmjerni. U ovome radu svi su odnosi, pa i dvije temeljne semičke kategorije, prikazani kao dvosmjerni koji se međusobno determiniraju. Time je omogućeno uvođenje vremenske dimenzije (predstavljene debljim strelicama) i dinamičnosti u inače statičnu narav semiotičkoga četverokuta. Između budućnosti i aktivizma, stvari kakve bi trebale biti, te prošlosti, sadašnjosti i svakodnevice, stvari kakve jesu, uspostavlja se vremenski kontinuum i međusobna uvjetovanost.

${ }^{17}$ Autorice zahvaljuju prof. dr. sc. Tomislavu Pletencu s Odsjeka za etnologiju i kulturnu antropologiju Filozofskoga fakulteta u Zagrebu, koji im je u raspravi nakon izlaganja u Centru za kulturu Trešnjevka svrnuo pozornost na važnost tih relacija unutar semiotičkog četverokuta.

18 Pasionalna ili patemička, pragmatička i kognitivna dimenzija upotpunjuju područje ljudske afektivnosti kako ga opisuje tzv. semiotika strasti. Afektivnost, koja u perspektivi semiotike strasti ima uporište u ljudskoj tjelesnosti, tu nije određena kao puka iracionalna komponenta ljudskog iskustva. U tom je teorijskom okviru smještena na dubinsku razinu smisla i posjeduje vlastite dinamike koje, kad se društveno i kulturološki ostvare, mogu generirati ili akciju (pragmatička dimenzija) ili razum (kognitivna dimenzija) ili strast (pasionalna ili patemička dimenzija) (Marrone 2001: 125). 
tucija, Povorka je ponosa usmjerena prema poboljšavanju i unapređivanju stvari za budućnost, ali određujući se u odnosu prema prošlosti i sadašnjosti: stvari kakve su bile i kakve jesu određuju kakve bi one trebale biti u budućnosti. U tome se smislu Povorka ponosa nalazi u neprestanoj relaciji prema prošlosti i sadašnjosti u kojima se ogleda i ogledajući se u njima modificira svoje prakse. Iz prošlosti i sadašnjosti se također crpe značenja i opća mjesta za konstrukciju LGBT povijesti, pamćenja i identiteta.

\section{PREIMENOVANJE ULICA NA ZAGREBAČKOJ POVORCI PONOSA}

Kako je već napomenuto, za vrijeme održavanja Povorke ponosa, zasad jednokratno samo 2010. godine, poduzeta je akcija preimenovanja ulica i trgova na ruti kojom se povorka kretala. ${ }^{19} \mathrm{Tu}$ aktivnost u ovome radu promatramo kao čin toponimskog otpora kojim podređene grupe preimenujući mjesta, odnosno preoblikujući toponimski krajolik, iskazuju simbolički otpor ideologiji dominantne grupe. Prisvajajući moć koju u stvarnosti nemaju, one šalju poruku o svojoj, doduše privremenoj i simboličkoj, "kontroli nad simboličkom infrastrukturom zajednice" (Rose-Redwood i sur. 2010: 460) te ostvaruju ograničenu i privremenu vidljivost. Kao primjeri takva toponimskog otpora mogu se spomenuti aktivnosti poput ispravljanja imena gradova, kvartova i sličnog na prometnim znakovima, njihova bojanja, križanja, preispisivanja itd. ${ }^{20}$ Također se usredotočujemo na značenjske konstrukcije koje su činom toponimskog otpora obznanjene $\mathrm{u}$ javnome prostoru i ispitujemo narav njihova odnosa s pamćenjem, poviješću i LGBT identitetima.

U Povorci ponosa 2010. godine organizatori nisu bili pretjerano radikalni pa nisu narušili i vandalizirali javnu imovinu preljepljivanjem ili šaranjem, već su promijenjene hodonime najavljivali megafonom na ulasku u ulicu ili dolasku na trg. Taj bi novi hodonim bio nošen kao transparent do sljedeće ulice odnosno trga. Transparenti s novoizmišljenim hodonimima bili su uni-

${ }^{19} \mathrm{Na}$ pitanje o razlozima jednokratnosti preimenovanja ulica nije moguće dati jednoznačan i konačan odgovor. Rasprava o tome nadilazila bi mogućnosti i okvire ovoga rada. Potrebno je, ipak, spomenuti da se na stranicama udruge Zagreb Pride može saznati da su njezine aktivnosti brojne i raznolike, ali i to da se dio njih nikada nije ponovio (ili se ponovio samo jednom), stoga se može zaključiti da ova aktivnost u tom smislu ne predstavlja iznimku. Mnoge su aktivnosti usmjerene upravo prema simboličkom zaposjedanju i pokvirivanju središta glavnoga grada: primjerice, Flashmob iz 2008. i 2009. godine, kad se velik broj osoba okupio u središtu Zagreba i izmjenjivao poljupce s osobama istoga spola ili podizanje zastave duginih boja na Trgu bana Jelačića svake godine za vrijeme tzv. Pride tjedna i sl. I srodne udruge poduzimaju aktivnosti sličnoga tipa, primjerice Queer Zagreb sa svojim također jednokratnim projektom queer zebre.

${ }^{20}$ Recentniji je primjer takve transgresije akcija nekoliko riječkih udruga pod nazivom "Ulice ženama”, kojom su u Rijeci na Međunarodni dan žena 2015. godine prelijepljena imena ulica imenima istaknutih žena koje su svojim kulturnim, političkim i javnim djelovanjem doprinijele jačanju ženskih prava, znanstvenim i teorijskim dostignućima te su tako odigrale važnu ulogu u oblikovanju društva (http://www. pariter.hr/?p=1056; pristup lipanj 2015.). 
formni i vizualno su podsjećali na službene ploče s imenima ulica: imena su bila napisana velikim štampanim slovima bijele boje na tamnoplavoj pozadini, a jedino što je nedostajalo da bi bila identična službenima jest bijeli obrub tipičan za tadašnje službene ploče s imenima zagrebačkih ulica i trgova. Odabirom upravo takvih slova i boja ti transparenti ne samo da podsjećaju na službene ploče, već na njih upućuju, na njih se pozivaju i iz njih crpe svoje ovlasti.

Naime, kako je ovlaštenost i za imenovanje (odnosno preimenovanje) i za postavljanje ploča s uličnim imenima zakonski regulirana - i u ovlasti je lokalne ili državne uprave - evociranjem službenih ploča s uličnim imenima briše se opreka između službenih znakova koje postavljaju vlasti (government signs; Landry i Bourhis 1997; vidi i Backhaus 2006), ${ }^{21}$ odnosno znakova top - down (Ben-Rafael 2009), kao što su ploče s nazivima ulica postavljene na zgrade ili stupove te neslužbenih, odnosno privatnih znakova (Landry i Bourhis 1997; vidi i Backhaus 2006) ili znakova bottom - up (Ben-Rafael 2009), kakvi su transparenti s imenima ulica. To upućivanje na službeni čin imenovanja aktivistima omogućuje simboličko prisvajanje ovlasti za imenovanje i za kreiranje novog pokvirenog prostora, što u konačnici proizvodi jedan novi plan grada koji evocira drukčiju prošlost.

\section{Virtualna šetnja rutom Povorke: analiza novih imena ulica}

U nastavku teksta "virtualno" se prolazi rutom kojom je te godine prošla Povorka ponosa uz analitički osvrt na svako preimenovanje. Povorka je, dakle, krenula s Trga žrtava fašizma i prošla Ulicom Račkoga preko Trga hrvatskih velikana, Jurišićevom, preko Jelačićeva trga, Gajevom i Teslinom do Zrinjevca (vidi sliku 1). ${ }^{22}$ Riječ je o osam hodonima, odnosno pet imena ulica i tri imena trgova, od kojih samo jedno ime nije promijenjeno i to prvo: Trg žrtava fašizma. Ono je ostalo u prvobitnom obliku zbog antifašističkih temelja udruge koja organizira zagrebačku Povorku ponosa i koja sebe karakterizira kao queer-feminističku i antifašističku grupu. ${ }^{23}$ Zadržavanjem tog hodonima LGBT zajednica se uspostavlja kao politički subjekt čije djelovanje nije usmjereno samo prema "unutra", prema LGBT zajednici samoj, već i prema široj zajednici, čiji je, napokon, ona i dio. Na taj se način uspostavlja i

${ }^{21}$ Opreka između službenih i privatnih (neslužbenih) javnih znakova u nekim kontekstima može biti problematična. Da vlast nema ili ne mora uvijek imati jednaku moć i kontrolu nad službenim znakovima, u Hrvatskoj pokazuje nedavno opetovano razbijanje dvojezičnih ploča u Vukovaru, odnosno sprečavanje institucija vlasti da takve ploče uopće i postave u javni prostor.

${ }^{22}$ Podaci o ruti Povorke i preimenovanim ulicama preuzeti su s: http://www.zagreb-pride.net/ povorka-ponosa-lgbtiq-osoba-zagreb-pride-2010-hrvatska-to-moze-progutati/ (pristup listopad 2015.).

${ }^{23}$ To je i naglasila krovnim sloganom pod kojim se 2015. godine odvijala Povorka ponosa: “Glasnije i hrabrije - antifašizam bez kompromisa". 
veza s antifašističkom poviješću grada, ali i s antifašističkim svjetonazorom uopće, i zajednica se prisvajanjem tog imena upisuje u povijest kao njezin sastavni dio.

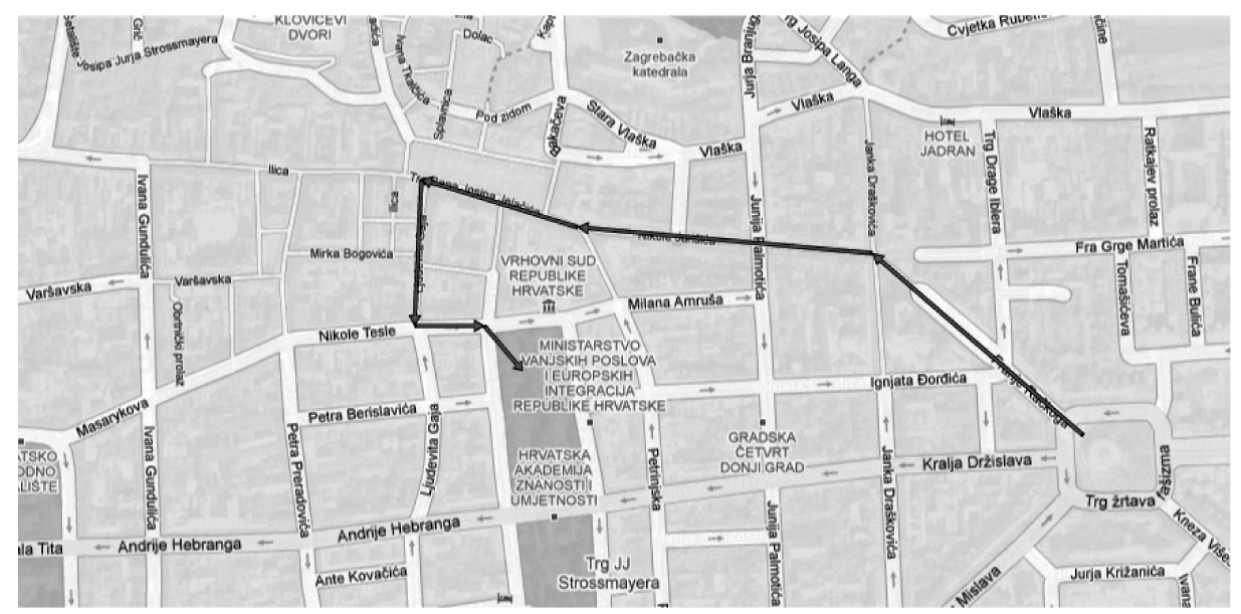

Slika 1: Ruta Povorke ponosa 2010. godine: crvena linija pokazuje ulice koje su bile preimenovane

Prva preimenovana ulica ona je Franje Račkoga, a njezino novo ime glasilo je Bipsić Straße. Taj dvočlani hodonim s jedne strane čine junaci crtanog filma Bipsići (u originalu The Biskitts), koji je 1980-ih prikazivan i na hrvatskoj televiziji, a čiji se naziv uvriježio kao slengovski izraz za biseksualne osobe. Usprkos ludičkom elementu kojim se priziva slika malih slatkih psića, time se odaje počast biseksualnim osobama, jednom od segmenata LGBT populacije. S druge strane, korištenjem njemačke riječi za ulicu (Straße) evociraju se nekadašnja dvojezična njemačko-hrvatska imena, odnosno komemorira se zagrebačka agramerska prošlost, čime se učvršćuje veza pripadnika seksualnih i rodnih manjina (odnosno prvenstveno biseksualnih osoba, a onda analogijom i ostalih) s gradom i njegovom srednjoeuropskom prošlošću. To pak sugerira da pojava homoseksualnosti, biseksualnosti, a onda i transrodnosti nije nešto što je "uvezeno sa zapada", kako se nerijetko može pročitati u medijskim tekstovima i službenim govorima političkih i javnih aktera, već postoji i u povijesti ovoga grada. Isto tako, tim lingvistički zanimljivim i neuobičajenim spojem hrvatskog slenga i njemačke riječi istodobno se konotiraju i suvremenost i prošlost. Time se biseksualne osobe upisivanjem u prostor upisuju i u povijest.

Sljedeći na ruti bio je Trg hrvatskih velikana, koji ne samo da ima bogatu povijest preimenovanja (ime mu se mijenjalo od Trga Burze preko Washingtonova trga, Trga münchenskih žrtava i Trga Jože Vlahovića do sadašnjeg imena), već se između 1990. i 2001. godine Trgom hrvatskih velikana na- 
zivalo mjesto sadašnjeg (i nekadašnjeg) Trga žrtava fašizma. Trg hrvatskih velikana, dakle, preimenovan je u Lezbožedni trg. Bez obzira na to je li u njegovu preimenovanju ulogu igrao i sam izgled trga (zbog fontana, na što upućuje pridjev žedni, a možda i zbog njihova trokutastog oblika koji može podsjetiti na određeni dio ženske anatomije, što je nesumnjivo zaslužno da su baš lezbijke "dobile" taj trg), novotvorena složenica lezbožedni upućuje na dva sloja interpretacije. U prvom sloju ta je riječ tvorena jednostavno od imenice lezba i pridjeva žedni, no konotativno se nameće još jedna interpretacija: lezbožedni svojom tvorbom na paradigmatskoj razini doziva pridjev krvožedni, što sugerira stereotip o lezbijskoj agresivnosti. Tim sklopom se uz riječ lezba, koja se ovdje upotrebljava kao pozitivno konotirana riječ kojom se lezbijke s ponosom identificiraju i na taj joj način oduzimaju moć da uvrijedi, povrijedi ili jednostavno negativno odredi grupu i njezine članice, jezično prisvaja i stereotip o agresivnim, ratobornim lezbijkama. ${ }^{24}$

No preimenovanje u Lezbožedni trg ne zaustavlja se samo na rekontekstualizaciji stereotipa i jezičnom prisvajanju prvotno pejorativne odrednice skupine. Zamjena velikana (agresivnim) lezbijkama nemalom ironijom sugerira da žene (i to ne nužno heteroseksualne) mogu stajati na mjestu zaslužnih i uglednih heteroseksualnih muškaraca (njihova se heteroseksualnost - u heteronormativnom društvu - uglavnom podrazumijeva), no to se ne potvrđuje u realnosti. Primjerice, prema istraživanju iz 2006. godine provedenom na razini Republike Hrvatske (Kodrnja 2006), samo 5\% osobnih imena upisanih u ulična imena otpada na žene; muškaraca je, dakle, 95\%. U samom središtu Zagreba nema niti jednog ženskog imena ulice, dok su na Gornjem gradu dva: Trg Katarine Zrinske i Dubravkin put. U vezi s potonjim potrebno je napomenuti da je Dubravka lik iz Gundulićeve drame, što je vrlo čest slučaj kod pripisivanja imena ulicama: znatan broj ženskih imena korištenih u hodonimiji zapravo otpada na imena fiktivnih likova iz djela koje su napisali muškarci, dok obrnutih slučajeva nema. Kod ovog se preimenovanja, pak, u prostor upisuju žene, i to lezbijke, i posredno se, zbog neraskidive veze prostora i vremena - $\mathrm{i}$ to ne samo u kvantnofizikalnom smislu prostorvremena, već i u poimanju prostora kao "društveno-povijesnog oblikovanja ljudskog svijeta" (Bosanac 2006) - upisuju i projiciraju u prošlost.

Sljedeća ulica, Nikole Jurišića, bila je preimenovana je u Trans aleju, čime se još jedan segment gej populacije, odnosno transrodne osobe, posredstvom prostora upisuje u povijest. Osim toga, promjenom urbonimnog termina, iz ulice u aleju, dakle iz obične u široku, lijepu prometnicu koja je s obje stra-

${ }^{24}$ Primjera jezičnoga prisvajanja ima i među sloganima (usp. Bertoša i Antulov 2012). Tako, primjerice, gej muškarci prisvajaju pogrdnu etiketu peder i njezinu pejorativnu uvećanicu pederčina i ne samo da ih nose s ponosom (Peder u duši, 2007), već i od drugih zahtijevaju poštovanje dok im se tako obraćaju (Gospodin pederčina, molim!, 2008). Ovdje se može spomenuti i slogan Živjela perverzija (2006), kojim se negativno konotiran seksualni interes i aktivnosti pozitivno određuju i veličaju. 
ne omeđena drvoredima - a Jurišićeva bi se možda tako i mogla definirati - naglašava se važnost tog, i u samim aktivističkim krugovima, često zanemarivanog segmenta LGBT populacije. Komemorativna počast transrodnim osobama u LGBT pokretu može se iščitavati i iz realnog prostornog smještaja Jurišićeve ulice, odnosno Trans aleje: riječ je, naime, o ulici/aleji koja izlazi na Trg bana Jelačića, središnji trg glavnoga grada Republike Hrvatske, koji je preimenovan u Trg Stonewallske pobune. Realna prostorna veza prebačena je na taj način i na simboličku razinu, jer su upravo transrodne osobe i transvestiti stali na čelo pobune policijskoj raciji u njujorškom baru Stonewall u ljeto 1969. godine koja se smatra prekretnicom i "protestom bez presedana u gej povijesti" (Rizzo 2011: 212).

Trg bana Jelačića aktivističkom je intervencijom, kako je već napomenuto, postao Trg Stonewallske pobune. Ban Jelačić (1801.-1859.) nacionalni je junak par excellence, a o njegovoj važnosti i za vrijeme njegova života dovoljno govori činjenica da je središnji zagrebački trg po njemu nazvan 1850. godine, dakle dok je još bio živ. Jedan toliko dugo vremena važan simbol, simbol oko kojeg se okuplja hrvatska nacija, simbol stvaranja nacije i ostvarenja "hrvatskog sna" u ovom se preimenovanju zamjenjuje simbolom začetka pokreta za prava osoba drukčije seksualne orijentacije i drukčijih rodnih identiteta. Promjenom simbola nacionalnog ponosa u simbol gej ponosa slažu se drukčiji komemorativni prioriteti (Azaryahu 2011). No ta imena nužno ne isključuju jedno drugo, već se uspostavlja ljestvica važnosti prema kojoj je gej ponos (eng. gay pride) iznad nacionalnog, kojem je time snižena razina važnosti. Dakle, simbol hrvatske nezavisnosti ustupa mjesto događaju koji označava početak svjetskog LGBT pokreta te se tako hrvatska LGBT zajednica povezuje sa svjetskom i, u nedostatku vlastitih mjesta pamćenja, preuzima strana i upisuje ih u prostor, što nije ni nova ni neobična taktika. ${ }^{25}$

Gajeva, možda i očekivano, igrom riječi postaje Gayeva [gejeva] ulica, što se ostvaruje jednostavnom zamjenom grafema " $j$ " i " $y$ ", odnosno glasova [a] i [e], čime se, zapravo, namjerno ili ne, vraća izvorna grafija imena Ludwiga von Gaya [gaja]. Tom se igrom riječi sugerira novo viđenje povijesti, u kojoj je uvažena povijesna ličnost (ne nužno sam Ljudevit Gaj) istodobno i pripadnik marginalizirane skupine, a fonološkom supstitucijom otvara se mogućnost za jednu novu, pokvirenu, verziju povijesti. Ovo je ujedno i jedini primjer u kojem izvorno ime ulice utječe na kreiranje novog imena, odnosno jedini slučaj u kojem se pojavljuje veza između izraza jezičnoga znaka starog i novog hodonima. Sve što je prije rečeno o upisivanju u prostor i prošlost vrijedi i ovdje.

${ }^{25}$ Primjerice, Praznik rada sjećanje je na demonstracije u Chicagu krajem 19. stoljeća, a ulica 1. svibnja postoji u mnogim hrvatskim gradovima. 
Teslina ulica postala je Ulica Zagreb Pridea, čime su organizatori Povorke sami sebi, odnosno svojoj udruzi, koja djeluje na lokalnoj razini, odali počast smatrajući je važnim društvenim akterom u području LGBT tematike. U odnosu prema sljedećem preimenovanom trgu koji je postao Park ponosa uočava se dvojezična englesko-hrvatska igra riječima kojom se naglašava važnost pojma ponosa u LGBT zajednici te unakrsno evociraju i povezuju globalni i lokalni segmenti gej povijesti i aktivizma. Točnije, lokalni segmenti se globaliziraju (ime lokalne udruge iskazano je na engleskom jeziku), dok se globalni prisvajaju lokaliziranjem (univerzalni pojam ponosa iskazan je na hrvatskom jeziku) čime se ujedno brišu granice između tih dviju dimenzija.

Završna točka šetnje je Trg Nikole Šubića Zrinskog koji sada nosi ime Park ponosa. Novo je ime sastavljeno od dviju značajnih komponenata: parka i ponosa. Park je, uz plaže, posebice nudističke, šetališta, kolodvore i sl. povijesno mjesto (homo)seksualnih susreta (za Hrvatsku vidi Dobrović i Bosanac 2007), koje s jedne strane svjedoči o društvenom potiskivanju gej populacije, njihovoj marginalizaciji, kriminalizaciji i patologizaciji. Svjedočanstva okupljena u publikaciji Usmena povijest homoseksualnosti u Hrvatskoj udruge Queer Zagreb nedvosmisleno dokazuju da je park Zrinjevac (kao i okolni parkovi) u prošlosti također funkcionirao kao mjesto na kojem su pripadnici gej populacije, većinom gej muškarci, tražili potencijalne partnere. S druge strane, parkovi i ostala mjesta homoseksualnih susreta mogu biti promatrani kao prostori snalaženja i komuniciranja, ostvarivanja vlastitih identiteta i žudnji, uspostave mreža interakcija i solidarnosti. Druga komponenta je pojam ponosa koji je već spomenut u kontekstu same Povorke i koji je vrlo važan koncept u LGBT pokretu i aktivizmu. Taj pojam označava taktiku kojom se marginalizirana grupa odbija sramiti zbog onoga što jest, te izražava ponos zbog svojeg identiteta. Park kao prostor koji bi se u nekoj drugoj, građanskoj, optici mogao smatrati mjestom srama, ovim se preimenovanjem koncipira kao mjesto na kojem LGBT osobe mogu slobodno, iako u realnosti okružene ogradama i jakim policijskim snagama, iskazivati sebe, svoj identitet i svoju žudnju te pritom biti ponosne.

U skraćenom preglednom prikazu postojeći hodonimi zamijenjeni su novima ovim redoslijedom:

1. Trg žrtava fašizma $\Rightarrow \operatorname{Trg}$ žrtava fašizma (nepromijenjeno; počast antifašističkoj povijesti Zagreba i Hrvatske)

2. Ulica Franje Račkoga $\Rightarrow$ Bipsić Straße (počast biseksualnoj populaciji)

3. Trg hrvatskih velikana $\Rightarrow$ Lezbožedni trg (počast lezbijkama, ženama)

4. Jurišićeva ulica $\Rightarrow$ Trans aleja (počast transrodnim i transeksualnim osobama)

5. Trg bana Jelačića $\Rightarrow$ Trg Stonewallske pobune (počast američkom gej pokretu, svojevrsnom ishodištu Povorki ponosa)

6. Gajeva ulica $\Rightarrow$ Gayeva ulica (počast gej muškarcima) 
7. Teslina ulica $\Rightarrow$ Ulica Zagreb Pridea (samopočast)

8. Trg Nikole Šubića Zrinskog $\Rightarrow$ Park ponosa (počast ideji da se ne treba sramiti zbog vlastite orijentacije)

Odabirom novih hodonima "pokrivena" su sva četiri fonema akronima LGBT koji, ako se konstruira redom koji slijedi rutu povorke, ima oblik BLTG. Ta permutacija osim svoje ludičke komponente sadržava i puno ozbiljniju poruku. Ona, naime, obrće vrijednosnu hijerarhiju unutar same LGBT zajednice i svjedoči o tome da su organizatori Povorke itekako svjesni činjenice da niti sama zajednica koju predstavljaju nije imuna na procese normiranja i marginalizacije određenih podskupina. ${ }^{26}$ Akronim BLTG na taj način predlaže nova prvenstva, odnosno obrtanje starih koji su uvriježeni $u$, gotovo politički korektnom, akronimu LGBT. Marginalizirani pripadnici biseksualne orijentacije, koji se često unutar zajednice ne doživljavaju dovoljno "ozbiljno" i kojima se u javnim diskursima nerijetko negira vlastiti identitet već ih se proglašava ili heteroseksualnima ili homoseksualnima, u novom poretku dobivaju prvenstvo. Lezbijke, koje su kao žene dvostruko marginalizirane, slijede za njima. Treće su transrodne i transeksualne osobe koje u historijskom smislu zapravo stoje na prvome mjestu, jer su upravo one i započele pobunu u Stonewallu (Price Minter 2006: 142). Posljednji su gej muškarci, možda i najmanje marginalizirana podskupina unutar LGBT manjine, za koje neki autori, primjerice Leap (2002: 49) primjećuju da i dalje prešutno ostaju univerzalnim subjektima bilo LGBT bilo queer studija. ${ }^{27}$ Novo uspostavljeni akronim BLTG možda toliko i ne predlaže novu hijerarhiju koliko odražava ideju obrtanja starog i ustaljenog fonemskog poretka i, s jedne strane, promiče svijest o pojmovima (akademskim i aktivističkim) kao konstruktima koji su u svakom trenutku podložni dekonstrukciji, dok s druge strane, evocira svijest o postojanju procesa marginalizacije unutar marginaliziranih skupina.

Obuhvaćanjem svih kategorija unutar LGBT pokreta u svakom je slučaju iskazana važnost svih (navedenih) skupina unutar raznolike zajednice seksualnih i rodnih manjina, što kao konačni cilj ima povezivanje i jačanje same zajednice. Svi se segmenti zajednice upisuju u prostor umjesto važnih historijskih ličnosti i na taj način zauzimaju njihovo mjesto u povijesti. To upisivanje ima važnu dvojaku ulogu: istodobno revidira opću povijest i konstruira zajedničku povijest LGBT zajednice.

${ }^{26}$ Da unutar gej i lezbijskih zajednica također postoji tendencija uspostave opozicije između normiranih subjekata i kategorija kojima će biti pripisane pozitivne i poželjne vrijednosti, te marginaliziranih subjekata i kategorija koji će biti markirani kao nepoželjni i Drugi, pokazala je Livia (2002) analizom osobnih oglasa iz pariškog lezbijskog časopisa Lesbia.

${ }^{27}$ Leap je, dakako, svjestan da su i gej muškarci heterogena kategorija, pa kad govori o njima kao univerzalnim subjektima queer i LGBT studija, ističe da misli na Europljanina i bijelca, pripadnika srednjega društvenog sloja. 


\section{Važnost zajednice, komemorativni prioriteti i simbolička revizija povijesti}

Nova imena ulica, dakle, ne imenuju konkretne osobe, kao što se to čini honorifikacijskim imenima kojima se komemoriraju zaslužni i dostojni pojedinci, odnosno velikani hrvatske povijesti i kulture. Upravo je suprotno: tu je na djelu komemoracija anonimnih članova zajednice. $S$ jedne strane novoizmišljeni hodonimi odaju počast junacima zajednice koje ne imenuju pojedinačno: u tom viđenju nisu bitna konkretna imena i prezimena, odnosno konkretne osobe već njihova pripadnost zajednici. Tim poopćivanjem uspostavlja se jednakost svih članova kao i svih navedenih skupina iz akronima LGBT. S druge se strane u novim hodonimima pojavljuju i pojmovi koji su, prema mišljenju organizatora, važni za lokalnu i globalnu LGBT zajednicu i pokret. Pojmovi poput pobune, ponosa i parkova na globalnoj i lokalnoj razini obilježavaju segmente LGBT povijesti koji postajući dijelom hodonima ulaze u kolektivno pamćenje. Pri tom je moguće uočiti slične pomake od prošlosti (stvari kakve jesu) prema budućnosti (stvari kakve bi trebale biti), koji su bili opisani i s pomoću semiotičkog četverokuta: potisnuta iz javnih prostora, gurnuta na društvene margine i osuđena na susrete u opskurnim parkovima, LGBT populacija uspostavila je mrežu međusobne komunikacije i solidarnosti te artikulirala ideju da se njezini pripadnici ne smiju sramiti svoje orijentacije; ideja je ponosa povezala i ojačala zajednicu iznutra te dovela do pobune koja je označila početak novog vala aktivističkih borbi za vlastita prava koji traje i danas, a nedvojbeno će trajati i u budućnosti, jer su "stvari kakve jesu" još daleko od "stvari kakve bi trebale biti".

No, ta podjela na anonimne osobe i koncepte može se promatrati u još jednoj perspektivi. U njoj pripadnici LGBT populacije i koncepti kao što su ponos, Stonewall, park i dr. zapravo funkcioniraju kao političko-aktivistički simboli. Oni se upisuju u prostor, a time se s pomoću njih preimenuje prošlost (Azaryahu 1996), odnosno revidira opća povijest i konstruira zajednička povijest i pamćenje LGBT zajednice.

Kako je ovlaštenost za imenovanje gradskih prostora u rukama vladajućih struktura, komemorativna imena ulica (kojima se najčešće odaje počast osobama i događajima) u svakodnevni život uvode službenu verziju povijesti (Azaryahu 1996). Stoga je zajednička prošlost koja se tako stvara - iako percipirana kao "dio prirodnog poretka" (Rose-Redwood i sur. 2010: 459) - ideološki filtrirana i, neminovno, nepotpuna. Ona uglavnom ne predstavlja marginalizirane skupine (npr. seksualne i rodne manjine, žene, strance, osobe drugih boja kože, drugih jezičnih izražaja), a oni za koje nema mjesta na pločama s hodonimima, zbog njihove odlike da istodobno predstavljaju prostornu odrednicu i referiraju na neko (prošlo) vrijeme, odnosno da spajaju prošlost s krajolikom, nevidljivi su i u prostoru i u vremenu. Stoga su 
komemorativna imena ulica moćno sredstvo kojim se urbani krajolik, koji nikad nije samo proizvod društvene moći nego i način njezina postizanja (Rose-Redwood i sur. 2010), pretvara u virtualnu političku arenu (Azaryahu 1996) u kojoj se onda može osporavati dominantna ideologija i uvoditi "alternativna kulturna značenja i narativi identiteta" (Rose-Redwood i sur. 2010: 463). Drugim riječima, takvim preispisivanjem krajolika marginalizirana skupina nastoji postići - i suvremenu i historijsku - vidljivost.

Dajući nova imena ulicama, trgovima i parkovima (čin koji uključuje političke, aktivističke i ludičke komponente), aktivisti urbanom toponimskom krajoliku daju drukčije komemorativne prioritete i upuštaju se u simboličku reviziju povijesti koja podsjeća na mjere koje se, još od Francuske revolucije, ${ }^{28}$ provode za vrijeme promjena političkih režima i revolucija (Azaryahu 1996; Rose-Redwood i sur. 2010). Preimenovanjem ulica nagoviješta se novi (queer) pogled na povijest koji priziva mogućnost da su neke od važnih povijesnih osoba bile pripadnici seksualnih ili rodnih manjina. Time se postiže još jedno brisanje: ovoga puta nametnute i umjetno stvorene granice između manjinske i većinske zajednice. Drukčijim komemorativnim prioritetima istodobno se konstruira i zajednička povijest LGBT zajednice, a pokvirena opća povijest i konstruirana LGBT povijest marginaliziranoj grupi daju osjećaj zajedničke prošlosti, identiteta, pripadnosti, kao i uključenosti u širu zajednicu.

Upisivanje drukčijih kulturnih značenja u prostor upućuje na alternativnu povijest u kojoj je marginalizirana skupina ravnopravno zastupljena i u kojoj se granice između manjinske i većinske kulture brišu. Tako zamišljena alternativna sadašnjost kreira novi plan grada, u kojem usprkos tome što "[p]rostorna organizacija uličnog nazivlja ne proizvodni nikakav značajan linearni slijed, a raskrižja ulica ne impliciraju nužno neku vremensku ili tematsku vezu između njihovih naziva [...] takva raskrižja, ipak, mogu sugerirati imaginarne susrete koji su ponekad prepuni ironije ili čak političke drame" (Azaryahu 1996: 327). Na novom planu grada Ulica Fra Grge Martića vodi do Lezbožednog trga, a Berislavićeva u Park ponosa; iz Palmotićeve se skreće u Trans aleju, dok Ilica započinje na Trgu Stonewallske pobune itd. Taj novi sustav uličnih imena simbolički i privremeno stvara alternativnu gradsku zonu u kojoj, primjerice, ulica Fra Grge Martića, Berislavićeva ili Palmotićeva egzistiraju usporedo s Parkom ponosa, Gayevom ulicom ili Lezbožednim trgom. U novom sustavu, dakle, velikani hrvatske kulture i politike supostoje s političko-aktivističkim simbolima LGBT pokreta i zajednice. Tako je proizvedena nova gradska zona s mjestima pamćenja koja marginaliziranu skupinu uključuje u svoje sustave vrijednosti, komemorira njezine članove i priznaje simbole njezine povijesti i identiteta. Uspostava

${ }^{28}$ Radikalne promjene hodonima "ugrađene su u sam početak građanske civilizacije" (Rihtman-Auguštin 2000: 61). 
novih mjesta pamćenja s opisanim obilježjima mijenja sadašnjost u mjesto naklonjenije seksualnoj i rodnoj različitosti i drukčijim životnim stilovima, u mjesto minimalne diskriminacije i maksimalne vidljivosti.

\section{Vizualni semiotički način}

Iako nije bila raskošna kao kod, primjerice, slogana, vizualna komponenta transparenata s imenima ulica i trgova kojim je prolazila Povorka ponosa 2010. godine vrlo je značajna jer kromatski odabir upućuje na "prave" ploče s uličnim nazivljem. Imena su velikim štampanim slovima bijele boje bila ispisana na tamnoplavoj podlozi, a nedostajao je jedino bijeli obrub. Kako je već napomenuto, evociranjem službenih ploča s uličnim imenima briše se opreka između službenih znakova i neslužbenih znakova, a to aktivistima omogućuje simboličko prisvajanje ovlasti za kreiranje novog pokvirenog prostora.

Prisvajanje preimenovanjem je to više simboličko što nova imena ulica nisu bila fiksno postavljena u prostor (primjerice, prelijepljena preko stvarnih ploča s uličnim nazivljem ili postavljena u njihovoj blizini), ${ }^{29}$ već su kao transparenti nošeni na čelu povorke kroz određenu ulicu odnosno trg. To što su aktivisti nova imena samo pronijeli kroz grad pojačava privremenost i prolaznost tog simboličnog prisvajanja, i s te se strane može smatrati da intervencija u prostor nije dokraja izvršena. No, s druge strane, namjera je jasno iskazana i postignuta je svojevrsna vjerodostojnost prepoznatljivim vizualnim elementima: kako je već napomenuto, uniformnost i kromatske odlike transparenata koji nose imena ulica i trgova prizivaju službeni izgled stvarnih ploča, a time i autoritet onih koji imaju ovlaštenje za postavljanje uličnih znakova, uključujući one s imenima ulica. Imitacijom izgleda pravih ploča s uličnim imenima aktivisti na sebe preuzimaju "ovlaštenost" za imenovanje ulica, čime se iz marginalizirane skupine "izdižu" ne samo u onu većinsku, već u onaj dio dominantne skupine koji ima političku i društvenu moć, koju oni tim činom simbolički i trenutno prisvajaju.

Kako je svako preimenovanje istodobno i iskazivanje autoriteta (Azaryahu 1996), odnosno (političke) moći, LGBT manjina na sebe je preuzela ovlasti koje inače nema i upisala se (ili se barem pokušala upisati) u prostor u kojem dotad za nju nije bilo mjesta. A kako je preimenovanje i čin prisvajanja (Azaryahu 1996), ona je i prisvojila javni prostor u kojem se nalazila, preuzela ga i tako ga učinila manje diskriminatornim i sigurnijim. Proizvedena je nova vrsta prostora, neheteroseksualni krajolik, odnosno queer krajolik, i to je učinjeno u samom centru grada, koji se uvijek visoko vrednuje i obilježava

${ }^{29}$ No to bi možda dovelo do brze intervencije komunalnih redara u smislu skidanja postavljenih natpisa i (novčanih) sankcija ili pak do nasilja desničarskih skupina. 
vrlo važnim osobama (rjeđe simbolima), jer upisivanje u središnje mjesto (trg i glavnu ulicu) označava njihovu simboličku važnost i društvenu moć (Kodrnja 2006). Na simboličkoj razini, pokvirivanjem centra grada pokviruje se cijeli grad.

\section{PREMA ZAKLJUČKU}

Preimenovanje ulica koje je na zagrebačkoj Povorci ponosa poduzeto 2010. godine u ovom je radu promatrano kao praksa s pomoću koje se konstruira i komunicira kolektivna memorija jedne marginalizirane skupine i u obliku toponimskog otpora upisuje u semiotički krajolik. Uočena je dvojaka narav konstrukcije pamćenja, koja uključuje globalne momente (primjerice, aktivizam koji se oslanja na Stonewallsku pobunu) te lokalne i regionalne elemente iz prošlosti i sadašnjosti (primjerice, povezivanje s gradskim prostorom i prošlošću grada u preimenovanjima kao što je Bipsić Straße i Gayeva ulica). Isto tako, istaknuta je važnost koncepata kao što su ponos i iskorak koji postaju važni aktivističko-politički simboli s pomoću kojih marginalizirana skupina konstruira svoj identitet i priprema bolju budućnost. Viktimizacija istospolnih osoba, evocirana primjerice u pobuni u Stonewallu, i otpor koji je sama gej populacija poduzela protiv toga - politički aktivizam - funkcioniraju kao topoi LGBT povijesti, ali i svakodnevice.

Osim toga, novoizmišljeni hodonimi ujedno nude novi pogled na povijest: upisivanje drukčijih kulturnih značenja u prostor upućuje na stvaranje alternativne povijesti u kojoj je marginalizirana skupina ravnopravno zastupljena. U takvoj alternativnoj povijesti izdvajaju se dvije dimenzije: lokalna i globalna. U lokalnu dimenziju povijesti upisuju se agramerske i mitteleuropske konotacije koje uspostavljaju kontinuitet i suživot u odnosu između LGBT populacije i stanovnika grada Zagreba (pa i šire) u prošlosti i sadašnjosti. U globalnoj dimenziji sadržane su konotacije antifašističkog svjetonazora i topoi LGBT povijesti, dakle, otpori ugnjetavanju, pobune, koncept ponosa, prisvajanjem kojih zajednica postaje dijelom svjetske povijesti. Time se stvara zajednička povijest i pamćenje LGBT zajednice koji nisu odvojeni od "službenih" verzija povijesti, već integrirani u njih jer upravo u njima nastoje stvoriti prostor za sebe. Drugim riječima, transformacijom semiotičkog krajolika i preispisivanjem povijesti zahtijeva se prihvaćanje i inkluzija. Tu je zato riječ o konstrukciji alternativne povijesti i sadašnjosti u kojima nema razlike između manjinske i većinske kulture, odnosno o verzijama povijesti i sadašnjosti koje ne marginaliziraju LGBT populaciju, ali niti toleriraju njezino postojanje u izdvojenim getoiziranim zonama, već je u cijelosti prihvaćaju i integriraju u svoja mjesta komemorirajući njezine zasluge, identitete, povijest i kolektivno pamćenje. Time je sadašnjost promijenjena u mjesto tolerancije i priznanja 
u kojem postoje minimalna diskriminacija i maksimalna vidljivost. Isto se može zaključiti ako se novoimenovane ulice promatraju kao dio postojećeg sustava hodonima u središtu Zagreba. U takvoj perspektivi novoimenovane ulice uklapaju se u sustav susjednih ulica kreirajući zajedno s njima novi plan središta grada koji svjedoči o priznavanju i prihvaćanju LGBT populacije kao ravnopravnog člana društva. ${ }^{30}$

Višeslojna i raznolika značenja evocirana novim hodonimima pojavljuju se kao specifična forma intertekstualnosti (Violi 2010), a organizirana su u različitim smjerovima: istodobno evociraju prošlost i sadašnjost, usmjeravajući se i prema budućnosti. U svojem činu preimenovanja aktivisti prisvajaju i resignificiraju relevantne pojmove, ukidaju granice između globalnog i lokalnog, većinskog i manjinskog, službenog i privatnog, te obrću uloge društvenih aktera i njihove pozicije moći. U takvim značenjskim organizacijama ističu se dva temeljna obilježja pamćenja: njegova multidirekcionalnost i njegova transkulturalnost.

\section{NAVEDENA LITERATURA I IZVORI}

Assmann, Aleida. 2011. Duga senka prošlosti. Beograd: Biblioteka XX vek.

Assmann, Jan. 2006. “Kultura sjećanja”. U Kultura pamćenja i historija. Maja Brkljačić i Sandra Prlenda, ur. Zagreb: Golden marketing-Tehnička knjiga, 45-78.

Azaryahu, Maoz. 1996. "The Power of Commemorative Street Names". Environment and Planning D: Society and Space 14/3: 311-330. [http://dx.doi.org/10.1068/d140311]

Azaryahu, Maoz. 2011. "The Critical Turn and Beyond. The Case of Commemorative Street Naming". ACME: An International E-Journal for Critical Geographies 10/1: 28-33. Dostupno na: http://ojs.unbc.ca/index.php/acme/index (pristup kolovoz 2015.).

Backhaus, Peter. 2006. "Multilingualism in Tokyo. A Look into the Linguistic Landscape". International Journal of Multilingualism 3/1: 52-66. [http://dx.doi. org/10.1080/14790710608668385]

Ben-Rafael, Eliezer. 2009. "A Sociological Approach to the Study of Linguistic Landscape". U Linguistic Landscape. Expanding the Scenery. Elana Shohamy i Durk Gorter, ur. New York: Routledge, 40-54.

Bertoša, Mislava i Sandra Antulov. 2012. “'Ovo su naša četiri zida'. Slogani zagrebačkih povorki ponosa kao taktika prisvajanja prostora”. Društvena istraživanja 117: 771-791.

Bosanac, Gordana. 2006. "Odsutan prostor žene. Povijest, javnost i svijet". U Rodno/spolno obilježavanje prostora i vremena u Hrvatskoj. Jasenka Kodrnja, ur. Zagreb: Institut za društvena istraživanja, 51-69.

Carter, David. 2011. Stonewall. Pobuna koja je rasplamsala gej revoluciju. Zagreb: Udruženje Zagreb Pride.

Demaria, Cristina. 2006. Semiotica e memoria. Roma: Carocci.

${ }^{30} \mathrm{Ne}$ treba, dakako, zaboraviti da je ovdje riječ o privremenim i prolaznim kreacijama koje samo prenose poruku o tome kako bi stvari u budućnosti trebale izgledati. 
Dobrović, Zvonimir i Gordan Bosanac, ur. 2007. Usmena povijest homoseksualnosti u Hrvatskoj. Zagreb: Queer Zagreb.

Floch, Jean-Marie. 1997a. Semiotica, marketing, comunicazione. Dietro i segni, le strategie. Milano: Franco Angeli.

Floch, Jean-Marie. 1997b. Identità visive. Costruire l'identità a partire dai segni. Milano: Franco Angeli.

Greimas, Algirdas Julien. 1991. Semiotica e scienze sociali. Torino: Centro Scientifico Editore.

Greimas, Algirdas Julien i François Rastier. 1968. "The Interaction of Semiotic Constraints". Yale French Studies 41: 86-105.

Halbwachs, Maurice. 1992. On Collective Memory. Chicago, London: The University of Chicago Press.

Isnenghi, Mario. 1997. "Presentazione”. U I luoghi della memoria. Mario Isnenghi, ur. Roma, Bari: Editori Laterza, I-XII.

Johnston, Lynda. 2002. "Borderline Bodies". U Subjectivities, Knowledges and Feminist Geographies. Liz Bondi et al., ur. Lanham: Rowman \& Littlefield, 75-89.

Kodrnja, Jasenka. 2006. "Rodna/spolna hijerarhija javnog prostora ili žene u nazivima ulica i trgova u Republici Hrvatskoj". U Rodno/spolno obilježavanje prostora i vremena u Hrvatskoj. Jasenka Kodrnja, ur. Zagreb: Institut za društvena istraživanja, 81-106.

Landry, Rodrigue i Richard Y. Bourhis. 1997. "Linguistic Landscape and Ethnolinguistic Vitality - An Empirical Study". Journal of Language and Social Psychology 16/1: 23-49.

Leap, William. 2002. "Not Entirely in Support of a Queer Lingusitics". U Language and Sexuality. Contesting Meaning in Theory and Practice. Katryn Campbell-Kibler, Robert J. Podesva, Sarah J. Roberts i Andrew Wong, ur. Stanford: CSLI Publications, Center for the Study of Language and Information, 45-63.

Le Goff, Jacques. 1977. Storia e memoria. Torino: Einaudi.

Livia, Anna. 2002. "Camionneuses s'abstenir. Lesbian Community Creation through the Personals". U Language and Sexuality. Contesting Meaning in Theory and Practice. Katryn Campbell-Kibler, Robert J. Podesva, Sarah J. Roberts i Andrew Wong, ur. Stanford: CSLI Publications, Center for the Study of Language and Information, 191-206.

Luongo, Michael. 2002. "Rome's World Pride Making the Eternal City an Internationl Gay Tourism Destination". GLQ 8/1-2: 167-181. [http://dx.doi.org/10.1215/10642684-8-12-167]

Marrone, Gianfranco. 2001. Corpi sociali. Torino: Einaudi.

McHale, Brian. 1992. Constructing Postmodernism. London, New York: Routledge.

Nora, Pierre. 2006. "Između pamćenja i historije. Problematika mjestâ". U Kultura pamćenja i historija. Maja Brkljačić i Sandra Prlenda, ur. Zagreb: Golden marketing-Tehnička knjiga, 21-43.

Price Minter, Shannon. 2006. "Do Transsexuals Dream of Gay Rights? Getting Real about Transgender Inclusion". U Transgender Rights. Paisley Currah, Richard M. Juang i Shannon Price Minter, ur. Minneapolis, London: University of Minnesota Press, 141-170.

Rihtman-Auguštin, Dunja. 2000. Ulice moga grada. Beograd: Biblioteka XX. vek.

Rizzo, Domenico. 2011. “Javne sfere i gej i lezbijske politike nakon Drugog svjetskog rata”. U Povijest gej i lezbijskog života i kulture. Robert Aldrich, ur. Zagreb: Sandorf, 197-221.

Rose-Redwood, Reuben S., Derek Alderman i Maoz Azaryahu. 2010. "Geographies of Toponymic Inscription. New Directions in Critical Place-Name Studies". Progress in Human Geography 34/4: 453-470. [http://dx.doi.org/10.1177/0309132509351042] 
Scollon, Ron i Suzie Wong Scollon. 2003. Discourses in Place. London, New York: Routledge.

Shugart, Helene A. 1997. "Counterhegemonic Acts. Appropriation as a Feminist Rhetorical Strategy". Quarterly Journal of Speech 83/2: 210-229. [http://dx.doi.org/ 10.1080/00335639709384181]

Skračić, Vladimir. 2011. Toponomastička početnica. Osnovni pojmovi i metoda terenskih istraživanja. Zadar: Sveučilište u Zadru.

Spolsky, Bernard. 2009. "Prolegomena to a Sociolinguistic Theory of Public Signage". U Linguistic Landscape. Expanding the Scenery. Elana Shohamy i Durk Gorter, ur. New York: Routledge, 25-39.

Violi, Patrizia. 2009. "Ricordare il futuro. I musei della memoria e il loro ruolo nella costruzione delle identità culturali". $E / C$, rivista on-line dell'Associazione Italiana di Studi Semiotici. www.ec-aiss.it (pristup srpanj 2015.).

Violi, Patrizia. 2010. "Il visitatore come testimone. Il Toul Sleng Museum of Genocide Crimes a Phnom Penh". U Testi e memoria. Semiotica e costruzione politica dei fatti. Maria Pia Pozzato, ur. Bologna: Il Mulino, 13-44.

\title{
A WALK FROM THE VICTIMS OF FASCISM SQUARE TO PRIDE PARK: A SEMIOTIC ANALYSIS OF SYMBOLIC STREET RENAMING AT THE ZAGREB PRIDE AS MEMORY PRACTICES
}

\begin{abstract}
SUMMARY
In this paper we analyse the act of symbolic renaming of streets included in the Zagreb Pride route, which has so far happened only once, in 2010. We view it as a practice that helps to construct and communicate collective memory of a marginalized group. The perspective in this paper is semiotic: the act of renaming is observed within the framework of relations among the constructions of meaning, history and memory. Using the examples of renamed streets, squares and parks, we show which elements of meaning are included in this construction. On the one hand, we observe the evocation of different significant events in the global LGBT history, and, on the other, we discern local (Zagrebian, national, Mittel-European) elements. We also explore the ways in which the local and global elements are intertwined and recontextualized in today's context and the relationship they create with history and space (the centre of the capital of the Republic of Croatia) into which they are inscribed.
\end{abstract}

Keywords: odonyms, renaming, linguistic landscapes, semiotics, memory, toponymic resistance 